\title{
VALUE CONCEPTS OF "ACCOUNTING POLICY" AND "BALANCE SHEET POLICY"
}

\author{
Marenych T. G. Doctor of Economic Sciences, Professor, \\ Polyvana L. A. Ph. D., Assoc., \\ Lutsenko O. A. Ph. D., Assoc. \\ Ukraine, Kharkiv National Technical University of Agriculture Petro Vasilenko
}

DOI: https://doi.org/10.31435/rsglobal_ijite/01062018/5679

\section{ARTICLE INFO}

Received 01 May 2018

Accepted 26 May 2018

Published 01 June 2018

\section{KEYWORDS}

Accounting policy,

balance sheet policy,

creative accounting

\begin{abstract}
The article considers the justification of its own theoretical approaches to accounting and balance policy on the basis of legal, scientific, and theoretical positions of their organization and proposes author definitions of the terms "accounting policy" and "balance policy".

The authors prove that the concept of "accounting" and "balance" policy coincides in part, at least in the word "politics". Although the content of these concepts covers common elements, we argue that each of these concepts also includes components that are not elements of another concept. It is stressed that these concepts can not be identified in any way.
\end{abstract}

(C) 2018 The Authors.

Introduction. Accounting policy is a subject of close supervision by interested individuals. It provides a legal way of adjusting the financial result and taxable income. The semantics of the term "accounting policy" includes determining the relationship between the two concepts "accounting policies" and "balance sheet policy". To date not specified and remains debatable definition of these concepts, and this in turn requires further research. We consider it appropriate to substantiate their theoretical approaches for accounting and book-based policy analysis of normative - legal and scientific - theoretical positions and their organization. We offer copyright definition of "accounting policies" and "balance sheet policy".

Research results. Modern realities operation of business entities requiring greater scientific substantiation pressing issues of organization and accounting and forming integrated scientific approach to the organization of accounting policies in the workplace. The formation accounting policy becomes more relevance in a view of global integration process in general and the constant restructuring of the economic system of the state in particular. We agree with a role-playing value of accounting policy, as we believe that the accounting policy of the enterprise has much wider significance: at the micro level - determining the tactics of financial and economic activities, the creation of an integrated system of accounting and analysis of enterprise and macro - forming is a common methodological framework of accounting at the national level [1].

Butynets F. F. notes that "accounting policy" is a set of actions on formation of complex teaching methods, techniques and procedures, organization and accounting that meets the peculiarities of the company, the interests of the owner and that should be considered in terms of the purpose of accounting" [2, p. 37]. Chatskis E. D., Lysyuk A. N., Mikhailov T. P. believe that the accounting policy is "... a set of accounting solutions to determine the outcome and results of the company, the financial statements" [3, p. 133]. M. V. Kuzhelnyy and V. Linnik, argue that the accounting policy - is "... a set of specific methods and means of organization and forms of accounting adopted now on the general rules and characteristics of his work" [4, p. 318]. Zagorodny A. G. takes the view that accounting policy is "... a set of methods of accounting (primary accumulation, cost measurement, current grouping and final generalization of economic activity) according to the characteristics of its economic activities" [5, p. 133]. Several researchers [6,7] interpret the term "accounting policy" according to the definition in the regulatory framework of Ukraine (changes in 2018), meaning by the term "accounting policy" is a set of methods of accounting that have been selected now for the preparation and financial statement presentation. Some other researchers clarify the concept of adding time accounting policy uncertainty factor of business entities, "Accounting policies - principles and rules of accounting; system methods and techniques of organization and accounting for specific 
businesses, secured appropriate normative act indefinitely " $[8,9,10]$. The modern approach to the definition of "accounting policies" are in the works of local $[11,12]$ and foreign scientists $[13,14]$ in accordance with international accounting standards and statements that interpret this concept as follows: "Accounting policies - the possibility to legally manipulate financial results in a particular company; specific principles, bases, conventions, rules and practices applied by an entity in preparing and presenting financial statements; deliberate design balance within the existing laws in compliance with generally accepted principles of an annual report". We believe that the accounting policies are based on financial image, because in it form the basic principles, methods and procedures. The presence of an effective accounting policy ensured accuracy and truthfulness performance indicators of economic activity of the entity, although their value depends on the alternative estimates of assets and liabilities. In determining the financial results influence the choice of accounting policies.

Our scientific position is more susceptible to the interpretation of the concept provided by B. Hurochkinoyu "accounting policy is a set of possible principles, methods and procedures used by the company to streamline and simplify the accounting process for the preparation and presentation of financial statements" [11, p. 25]. However, we consider it necessary to add to the understanding of the concept of accounting policies, some components. The first, indeed, according to the Law of Ukraine "On Accounting and Financial Reporting in Ukraine" accounting policy elected by the enterprise itself, but each of the principles, methods and procedures of accounting are governed by the relevant national or international standards, because clearly indicate the autonomy and isolation formation of accounting policy of government regulation is impossible. Second, creative accounting is alternative and independence of the election in accordance with prescribed act certain methods (eg, evaluation methods of agricultural production for a direct and indirect production costs, etc.) and other regulations state that most optimally meet future the specifics of the entity.

According to the Law of Ukraine "On Accounting and Financial Reporting in Ukraine" from 01.01.2018 has changed the definition of accounting policies. Renewed determination is accounting policies - a set of principles, methods and procedures used by the company for accounting, preparation and presentation of financial statements [15]. The accounting policy applies not only to financial statements, but also on accounting. International interpretation of accounting policy has a more individualized nature of the market that determines the efficiency maximize total capacity, making maneuvering assets and liabilities, and taking into account changes in market conditions in accordance with the strategy and tactics of a particular business entity. Thus, IAS 8 "Accounting Policies, Changes in Accounting Estimates and Errors" accounting policy is the specific principles, bases, agreements, rules and practices adopted by the company for the preparation and presentation of financial statements [16].

However, in recent years the term "accounting policy" is often replaced the synonymous term "balance sheet policy" which is taken from the register of Western Europe. The concept of balance policy appeared in the scientific literature in the 20's of the last century and was associated primarily with the formation process of accounting reports and balance studies stock companies. So far, there is discussion about the essence of the book policy, its meaning, purpose. Full coherence and clarity in defining the essence of the book policy, its relationship with accounting does not exist at present. Ambiguous scientific community in relation to the necessity of carrying enterprise policy. There are different views with respect legality and safety of balance sheet policy. Therefore, it is interesting review of these issues in the context of the views of scholars and practitioners of accounting. Traditionally, the book accounting policies realize a balance of renewal, in which accountants alter the capital structure and profit margins (under existing laws and subject to national principles preparation of annual reports). This is usually done in order to influence its key figures. In international practice is often possible to improve the reporting companies through manipulation, but only under certain practices or prevailing legislation.

Baranovska T. V. insists that "the main difference between the accounting policies and the book business is within range of each of them (for accounting policy - organization and accounting, for balance - financial reporting)" [17, p. 17].

Ivashkevich V. B. notes that accounting, including the carrying company policy determines the system development and financial disclosure about its activities and its results. An important part of this system, according to scientists, is carrying a set of policy methods final summarizing the facts of economic life. Carrying policy is an economic tool for managing business entities realized through the use of an executive staff of their actions to achieve profitability goals sooner or long-term efficient operation now [18]. 
In Western Europe the book policy is determined, usually in the short term (3 to 5 years) and must be specified annually at the discretion of the owners and top management of companies. To this end, they provided the balance sheet with attachments of previous years and design a creative balance to the current period.

The purpose of the financial statements (and in this case the balance) is to provide users with decision-making complete, accurate and unbiased information about the financial condition, results of operations and cash flows of the enterprise, then this information need as the company's management and its owners, financial bodies, lenders (banks), investors. Given the diverse needs of enterprises, usually consists of several balances "internal" and some "external." External balances act carrying objects implement policies and contain less profound, and often less reliable information for the realization of certain interests of companies. Internal balance sheets and statements of income consist of other criterias. They usually reflect the true financial position of the company and serve as information for guidance. Their main goal is liquidity analysis as entities rather die from a lack of liquidity than otherwise.

Measures balance policies are divided into those that can be taken the day before the balance sheet, and they are allowed only after the balance sheet [19, p. 41].

When carrying Zabbarova O. A. policies understands the balance of renewal, subject to applicable law within the regulation of accounting in which possible changes in capital structure and profit margins in order to affect the balance of key indicators [20, p. 200]. The author notes that the main purpose of the book is intended policy understating the profit opportunities under the tax laws in order to reduce taxes or the amount of dividends to shareholders and thereby increase the capital reserve. However, often the company's management, by contrast, deliberately increased profit margins in the balance, not to show poor financial situation of the company.

So, a system of accounting and financial accounting set the stage for the use of the book policy in which organizations, a new line of accounting - "creative" accounting. This account was established in 90 years of the twentieth century. Anglo - American accounting school, that using accounting methods allow people to decorate the firm's financial condition in the financial statements or to achieve other goals orders of senior management.

According to I. A. Yukhimenko-Nazaruk, creative accounting is a certain area of financial activity that involves the possibility of choosing among existing alternatives book display and in cases where there are no regulatory guidelines. The issue of creative accounting rather closely connected with issues of construction and implementation of accounting policies and exercise of judgment. At the same time creative accounting is a much wider sphere of activity because it includes not only accounting procedures that are focused on increasing the attractiveness of financial statements to stakeholders and reducing the tax burden for the company, but also the formation of projections and scenarios your display facts of economic life, analysis impact indicators performed procedures on accounting and management decisions of interested users [21, p. 429].

According to A. Karmanskoyi, creative accounting is positive when used without a direct violation of the law to reflect the major trends of economic activity and contributes to the flexibility of decision-making by providing minimize the risk of loss and high profitability management at the micro level. Otherwise - the process of decorating statements for the better reflect its activities for shareholders, investors and other stakeholders [22, p. 139].

Creative accounting often begins with direct illegal activities, but it all starts with choosing alternative accounting procedures and aggressive accounting methods that may not be illegal in itself. The issue is when the application of different accounting principles or changing accounting policies are appropriate is important, it Mokrynska Z. [23, p. 32].

Group of authors argue that accounting professionals can choose different methods and tools of creative accounting that allow them to submit financial position and results of the company in the best light. Consequently, it is unlikely that financial reporting is reliable. In accordance creative accounting information hinders objectivity [24, c. 54].

Based on the above it can be concluded that, on the one hand, the creative can be found either - which accounting method that does not meet generally accepted practice or the established principles and standards, and, on the the other hand, a process of providing information on accounting accounts so they helped in the interest of foreign users.

Thus, in our view, carrying and creative accounting policies involve a creative approach to the information provided in the financial statements. We believe that the book represents a policy is not so much fraud indicators balance as creative and very "creative" approach to regulation indicators of financial statements, including balance. In Ukraine maintaining balance policy should be carried out 
within existing laws and regulations in the field of accounting. Thus, the content of the book is policy on the one hand, within the regulatory accounting and the other is the driving force that provokes the further development of legislation on accounting methodology and accounting.

Conclusions. Thus, the carrying our own policy is to ensure that a set of measures allowed to manipulate the balance of performance to meet the interests of the company, carried out under the current legislation. Indeed, at first glance, there are similarities between the concepts of "accounting policy" and "balance sheet policy" which overlaps at least the word policy. Although the content of these concepts includes common elements, we argue that each of these concepts includes components that are not elements of a concept. These concepts in any case can not be identified.

For the completeness of the study, we give the actual definition of accounting policy. Accounting policy is a set of specific principles, methods and procedures for accounting in the system of financial and economic activity of the entity, formed on the basis of the legislative framework of the state on issues of counting and reporting, and secured by the relevant an internal - normative act, and also provides a creative, within the law, approach to minimize costs and maximize the profit of the entity. We believe that this interpretation of the essence of the concept of "accounting policy" harmonizes all the constituent elements of the accounting and analytical system in the context of financial and economic functioning of domestic enterprises. Moreover, the author's definition of this term allows expanding the concept of the stages of formation of accounting policies in the context of a systematic approach to its organization in the practice of management of domestic market players. It is etymologically speaking about accounting policies, as accounting policy is designed to provide the company with the necessary methods and methodological approaches to accounting and financial reporting.

The purpose of further research is to develop recommendations for the introduction into practice of the effective activity of the company standards and regulations on accounting policies, which will be able to actively influence the level of accounting.

\section{REFERENCES}

1. Polyvana L. A., Gubar A. A. Organizatsiya oblikovoyi polityky // Buhgalterskiy oblik i audyt. №5. S. 45-53.

2. Butynets F.F. Organizatsiya buhgalterskogo obliku: pidruchnyk dlya studentiv spetsialnosti «Oblik i audyt» vischyk navchalnykh zakladiv / za red. prof. F.F. Butyntsya. 3-e vyd. dop. i pererob. Zhytomyr: PP «Ruta», 2002. $-592 \mathrm{~s}$.

3. Chatskis E. D., Lysyuk A. N., Myhaylova T. P. Buhgalterskiy uchet aktivov, kapitala, obyazatelstv i hozyaystvennyh operatsiy. Donetsk: Don-DUET, 2001. $301 \mathrm{~s}$.

4. Kuzhelnyi M. V., Linnyk V. G. Teoriya buhgalterskogo obliku. K.: KNEU, 2001. 334 s.

5. Zagorodniy A. G., Partyn G. O. Buhgalterskyi oblik: osnovy teoriyi i praktyky. 3-te vyd., pererob. i dop. K.: T-vo «Znannya», KOO, 2004. 377 s.

6. Karpushenko M. Organizatsiya obliku: navch. posibnyk (dlya studentiv ekonomichnyh spetsialnostey, yaki navchayutsya za spetsialnistyu «Oblik i audyt»). H.: HNAMG, 2011.241 s.

7. Tsvetkova N. Suchasna organizatsiya obliku ta skladannya zvitnosti dlya priynyattya upravlinskyh rishen // Buhgalterskyi oblik i audyt. 2008. №3. S. $14-27$.

8. Buhgalterskyi slovnyk / za red. prof. F. Butyntsya. Zhitomyr: PP «Ruta», 2001. $224 \mathrm{~s}$.

9. Zhitnyi P. Organizatsiyno-metodologichni zasady formuvannya oblikovoyi polityky pidpriemstva // Buhgalterskiy oblik i audyt. 2006. №3. S. 3-10.

10. Suk P. Oblikova polityka pidpryemstva // Buhgalteriya v silskomu gospodarstvi. 2005. №1. S. $2-4$.

11. Gurochkina V. Kreatyvnyi oblik (stvorennya informatsiyi dlya menedzheriv) // Mizhnarodnyi zbirnyk naukovyh prats «Instytut buhgalterskogo obliku, kontrol ta analiz v umovah globalizatsiyi».. №2. Kam’yanets-Podilskyi, 2014. S. $24-28$.

12. Ohramovych O. Teoretychni ta praktychni aspekty formuvannya oblikovoyi polityky pidpryemstv v suchasnyh umovah gospodaryuvannya // Naukovyi ekonomichnyi zhurnal «Aktualni problemy ekonomiky». 2013. №5. S. $190-194$.

13. Sokolov Ya. Osnovy teorii buhgalterskogo ucheta: Monografiya. M.: Finansy i statistika, 2000. $496 \mathrm{~s}$.

14. Hoyer V. Kak sdelat bizness v Evrope: posobie dlya sotrudnikov vneshnetorgovyh organizatsiy, sovmestnyh predpriyatiy, smeshanyh firm, kooperativov. M.: Fond «Za ekonomicheskuyu gramotnost», 1991. $193 \mathrm{~s}$. 
15. Zakon Ukrainy «Pro buhgalterskyi oblik ta finansovu zvitnist v Ukraini», zatv. VRU vid 16.07.1999. №996-XIV zi zminamy ta dopovnennyamy // [Elektronnyi resurs]. Rezhym dostupu: http://zakon4.rada.gov.ua/laws/show/996-14.

16. Mizhnarodnyi standart fInansovoi zvitnosti 8 «Oblikovi polityky, zminy v oblikovyh otsinkah ta pomylky» [Elektronnyi resurs]. Rezhym dostupu: http://zakon3.rada.gov.ua/laws/show/929_020.

17. Baranovska T. V. Oblikova polityka pidpryemstv v Ukrayini: teoriya i praktyka. Avtoreferat disertatsiyi na zdobuttya naukovogo stupenya kandydata ekonomichnih nauk. K.: NAU, 2005. $23 \mathrm{~s}$.

18. Ivashkevych V. B. Rol balansovoi politiki v upravlenii predpriyatiem. IPB Rossii: Zhurnal «Vestnik professionalnyh buhgalterov». 2016. №1.

19. Mezhdunarodnyi buhgalterskii uchet. GAAP i IAS. Spravochnik buhgaltera ot A do Ya / Sost. Matveeva V.M. M.: Izdatelstvo «Delo i servis», 1998. 192s.

20. Zabbarova O. A. Balansovedenie. M.: Knorus. 2007. 256s.

21. Yuhimenko - Nazaruk I. A. Instytutsiyni aspekti realizatsii kreatyvnogo obliku v konteksti oblikovoyi polityky pidpryemstva. Problemy teorii ta metodologii buhgalterskogo obliku, kontrolyu i analizu. 2014. Vip. 3 (30). S. 428 - 438.

22. Karmanska A. Etyka w dydaktyce rachunkowosci / A. Karmanska // Zeszyty teoretyczne rachunkowosci. 2005. T. 26 (82). S. 138-165.

23. Mokrinska Z. V. Tvorchiy pidhid $\mathrm{v}$ buhgalterskomu obliku chy problemy etyky buhgaltera. Agrosvit. №6. 2015. S. 31-35

24. Moldovan R. L, Achim S. A., BotaAvram C. Fighting the Enemy of Fair View Principle. Getting to Know Creative Accounting. P. 51-61// http://anale.feaa.uaic.ro/anale/resurse/ctb5moldovan.pdf (Accessed 24 Desember 2014). 